REVISTA de

PEDAGOGIE

\title{
ACADEMIC SKILLS SELF-EFFICACY AND COLLEGE- GOING OUTCOME EXPECTATIONS AS PREDICTORS OF UNDERGRADUATES' SATISFACTION WITH THEIR CHOSEN AREA OF STUDY AND DROPOUT INTENTIONS
}

Autoeficienţa cu privire la deprinderile academice şi aşteptările legate de absolvirea facultăţii ca predictori ai satisfacţiei faţă de domeniul de studiu ales şi ai intenţiei de renunţare la facultate

\section{Raluca LIVINŢI, Dragoş ILIESCU}

Journal of Pedagogy, 2020 (1), 193 - 212

https://doi.org/10.26755/RevPed/2020.1/193

The online version of this article can be found at: http://revped.ise.ro/category/2020/

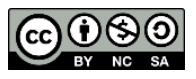

This work is licensed under the Creative Commons Attribution-NonCommercial-ShareAlike 4.0 International License.

To view a copy of this license, visit http://creativecommons.org/licenses/by-nc-sa/4.0/ or send a letter to Creative Commons, PO Box 1866, Mountain View, CA 94042, USA.

Published by:

Centrul Național de Politici și Evaluare în Educație

UNITATEA DE CERCETARE ÎN EDUCAȚIE

http://www.ise.ro/

https://rocnee.eu/

Further information about Revista de Pedagogie - Journal of Pedagogy can be found at:

Editorial Policy: http://revped.ise.ro/editorial-policy/

Author Guidelines: http://revped.ise.ro/the-writer-guide-2/ 


\title{
ACADEMIC SKILLS SELF-EFFICACY AND COLLEGE-GOING OUTCOME EXPECTATIONS AS PREDICTORS OF UNDERGRADUATES' SATISFACTION WITH THEIR CHOSEN AREA OF STUDY AND DROPOUT INTENTIONS
}

\author{
Raluca Livin i* \\ Dragoş Iliescu**
}

University of Bucharest,

Faculty of Psychology and Educational Sciences, Bucharest, Romania

raluca_livinti@yahoo.com,dragos.iliescu@fpse.unibuc.ro

\begin{abstract}
Building on the integrative model from the Social Cognitive Career Theory, the present study investigates in a longitudinal approach the association between students' academic skills self-efficacy, college-going outcome expectations, and intention to drop out of their academic studies, as mediated by satisfaction with their chosen area of study. It also investigates whether vocational fit/congruence adds an increment to the aforementioned variables in explaining the intention to drop out of university. The sample included 167 freshmen students in various areas of study who filled in questionnaires of self-efficacy, outcome expectations, and vocational fit in the first weeks at university. In the second semester, six months later, they filled in instruments that measure satisfaction with the chosen area of study and dropout intentions. The results showed that the best fit was that of a model in which satisfaction with the area of study is a full mediator of the relationship between self-efficacy and dropout intentions and between outcome expectations and dropout intentions. The Iachan and Zener-Schnuelle fit indices alone were a predictor of dropout intentions. However, its addition to the model does not bring an explanatory increment but rather leads to a poorer fit of the model. Implications are discussed.
\end{abstract}

* PhD Candidate, University of Bucharest, Faculty of Psychology and Educational Sciences, Bucharest, Romania.

** Professor, PhD, University of Bucharest, Faculty of Psychology and Educational Sciences, Bucharest, Romania. 
Keywords: academic skills self-efficacy, college-going outcome expectations, Holland congruence index, Social Cognitive Career Theory, university dropout.

\section{Rezumat}

Având drept cadru teoretic modelul integrativ din Teoria social-cognitivă a carierei, studiul de fa ă investighează într-o abordare longitudinală rela ia dintre autoeficacitatea cu privire la deprinderile academice, aşteptările pozitive legate de calitatea de absolvent al unei facultă $i$ şi inten ia de a renun a la facultate, având ca mediator satisfac ia cu profilul ales. Studiul investighează, de asemenea, dacă potrivirea/congruen a voca ională aduce un increment peste variabilele men ionate anterior în explicarea inten iei de a renun a la facultate. Eşantionul a fost format din 167 de studen i înscrişi în primul an în domenii diverse, care au completat instrumente de măsurare a autoeficien ei, a aşteptărilor și a potrivirii/ congruen ei voca ionale în primele săptămâni ale anului universitar. În al doilea semestru, şase luni mai târziu, au completat instrumente de măsurare a satisfac iei fa $\breve{a}$ de profilul ales şi a inten iei de a renun a la facultate. Rezultatele au arătat că cea mai bună potrivire o are un model în care satisfac ia fa ă de profilul ales este un mediator total în rela ia dintre autoeficien ă şi inten ia de a renun a la facultate şi în rela ia dintre aşteptări şi inten ia de a renun a la facultate. Indicii de potrivire Iachan şi Zener-Schnuelle au prezis inten ia de a renun a la facultate. $\mathrm{Cu}$ toate acestea, adăugarea lor la model nu aduce un increment explicativ, ci din contra, conduce la o potrivire mai mică a modelului. Sunt discutate implica iile.

Cuvinte cheie: abandon universitar, autoeficien $\breve{a}$ cu privire la deprinderi academice, aşteptări pozitive legate de calitatea de absolvent al unei facultă $i$, indicele de congruen ă Holland, Teoria social cognitivă a carierei.

\section{Introduction}

University dropout is an important topic in educational research, due to its economically, socially, and psychologically important implications. The social and economic importance of completing tertiary education has been acknowledged in the Europe 2020 strategy of the European Commission (European Commission, 2010), which proposed as target the growth of the population aged 30-34 that finished tertiary education from $31 \%$ to at least $40 \%$ by 2020 . For 2018 , the European average was $40.7 \%$, while the average in Romania was much lower, at $24.6 \%$ (European Commission, 2019). The same study showed the impact of tertiary level education on the employment rate. For Romania, the employment rate for an ISCED 5-8 educational level 
is $88.9 \%$, while for an ISCED 3-4 educational level the employment rate is much lower, at $67.7 \%$ (European Commission, 2019). Dropout has a significant economic effect, in the US people with college degrees earning an average hourly wage that is $65 \%$ higher than college dropouts (Gould, 2019). A synthesis of the statistical analyses conducted on the Romanian population regarding the beneficial effect of education on both occupation rate and salary can be found in Varly, Iosifescu, Fartuşnic, Andrei and Her eliu (2015). Also, dropout has important psychological effects on self-esteem (Hoeschler \& Backes-Gellner, 2017). We did not identify studies reporting on the psychological effects of dropout in Romania.

The statistical results regarding educational dropout in Romania inform the interest for this line of research, in order to limit its expansion and effects. For example, Eurostat shows that Romania was in 2018 in the third place in the European Union regarding early leavers from education and training between 18 and 24 years old, with 15.1\% (Eurostat, 2020). Although lower than in the previous years (for example, $18.5 \%$ for Romania in 2016), this level is still much higher than the average of the European Union (10.2\% in 2019).

Although the Romanian universities compute statistics regarding student dropout, those are seldom available publicly. Rare published examples are statistics presented in ANOSR (2014) and Stăiculescu and Richi eanuNăstase (2018). ANOSR (2014) reported that university dropout was as high as $40 \%$ for the graduating year 2012-2013, based on data from 20 state universities, bachelor degree studies. The results suggest that out of those $40 \%$ dropouts, $48 \%$ of students drop out in the freshman year, and $40 \%$ in the senior year. Stăiculescu and Richi eanu-Năstase (2018) reported statistics for the freshman year at the Bucharest University of Economic Studies (ASE), the biggest university with an economics profile in Romania, with more than 20000 students. For the academic years between 2013 and 2017, the lowest dropout rate was in the 2015-2016 academic year (14.32\%), while the highest was in the 2013-2014 academic year (16.28\%).

The psychological mechanisms of the dropout process have been under scrutiny especially due to the rise of the studies conducted in the Social Cognitive Career Theory (SCCT; Lent, Brown \& Hackett, 1994) framework. 
The present study contributes to the literature by reporting on research focused on academic dropout, conducted through the lens of SCCT and Holland's vocational interest theory.

\subsection{University dropout}

Dropout is defined in many alternative ways (Lee \& Choi, 2011; RodríguezGómez et al., 2015). In its most common meaning, university dropout focuses on students leaving university studies before earning a degree (Heublein, 2014); this is the definition that is habitually used in most studies. It has, however, a number of limitations, most notably an inherent difficulty in distinguishing between dropout and different forms of mobility (Heublein, 2014). For example, students may choose to transfer to another local or international university, give up their current enlistment in order to pursue a different area of study, finish university without the final exam, dissertation or thesis defense, or leave temporarily and come back later to graduate. In Romania, there is also a separate category of students who were declared accepted in the summer admission session, but whom, for various reasons (usually, because they have been admitted to several universities), do not confirm and sign the study contract in October and are officially declared dropouts by withdrawal. Other categories of officially reported dropouts are students who got expelled because they did not get the credits necessary to pass the undergraduate academic year or because they did not pay their fees - some of whom, to complicate matters even more, do not attend their exams and do not pay their fees as an implicit form of giving up on their studies.

The two models that were traditionally used in university dropout research are the Student Integration Model (Tinto, 1975) and Bean and Metzner's model of student dropout (1985).

Tinto's model states that student dropout is caused by a lack of congruency between themselves and the academic institution. Student motivation, academic achievement, and intellectual ability, along with social interaction with peers and the institution are postulated in this model to lead to goal and institutional commitment. Dropout occurs when goal commitment is present, 
but institutional commitment is absent. According to Bean and Metzner's model, several categories of factors, such as academic variables (the student's approach to study), academic outcomes (GPA), and environmental variables (such as finances and family context) lead to psychological outcomes (utility, satisfaction, goal commitment, and stress), to attitudes (that then lead to intention to leave) and finally to dropout behavior. The two models have their merits, especially by emphasizing the joint role of social and environmental factors and of academic factors in shaping dropout/persistence decisions. They also show a major limitation, in that that they both fail to consider intrinsic factors as predictors of college dropout (Cabrera et al., 1993).

Some individual factors have long been demonstrated to be positively related to the intention to withdraw from the university. Among them, there are factors such as gender (with male students being more prone to dropping out than female students), high school GPA, SAT scores, academic-related skills, and other numerous predictors (see Robbins et al., 2004). Studies also show that a key period for dropout is the second semester of study (GrauValldosera \& Minguillón, 2014).

\subsection{The SCCT and persistence intentions}

The SCCT is a vocational psychology theory that has been intensely researched in the past 25 years. It consists of several models that explain interest formation, career decision making, and performance (interest, choice action, performance, work and academic satisfaction models, and career management model) (Lent et al., 1994; Lent \& Brown, 2006; Lent \& Brown, 2013). The SCCT focuses on key concepts such as self-efficacy (domainspecific confidence about successfully engaging in an activity/task), outcome expectations (positive expectations from engaging in an activity), interest in specific activities, goals, and choice actions (e.g., pursuing a certain career, dropping out of college, etc.).

Social-cognitive factors play a central role in studies conducted in recent years and they prove to be good predictors for university persistence. Lent et al. (2013) suggested a combination of some of the paths in the other 
SCCT models and worked towards an integrative model, with academic persistence as a final outcome. Satisfaction with the pursued area of study, although initially not a part of the various SCCT models, began thus to be studied in relation with other SCCT variables, such as self-efficacy, outcome expectations, academic satisfaction, environmental supports and barriers, formed interests, personality features, and affective disposition.

A number of studies explored and supported the paths of this model. Selfefficacy has been found to be a predictor of academic satisfaction (Flores et al., 2014; Morris \& Lent, 2019; Mujica et al., 2019), as well as of academic persistence intentions, in cross-sectional designs (Garriott et al., 2017; Mujica et al., 2019) in longitudinal designs (Lent et al., 2015; Navarro et al., 2014), and in meta-analyses (Robbins et al., 2004), and it has also turned out to be a predictor of actual persistence four undergraduate semesters later (Lent et al., 2016). Academic satisfaction turned out to be an antecedent of intentions to persist (Lent et al., 2015; Lent et al., 2016; Morris \& Lent, 2019; Navarro et al., 2014). Satisfaction with major emerged as a mediator in the relation between the social-cognitive factors and intention to persist in the chosen major (Lent et al., 2016). Outcome expectations emerged as an antecedent of academic satisfaction and persistence in some of these studies, but not in all of them (Truong \& Miller, 2018).

However, all these studies conducted in the SCCT framework focused on persistence. To our knowledge, there are no studies focusing on actual dropout. At first sight, the two are conceptually opposed, persistence focusing on remaining enrolled in a chosen major until graduation - hence, not dropping out. Depending on the educational system and area of study, the focus can be on one of the two concepts. Studying persistence makes more sense for the US academic system, where not persisting may imply changing majors, but most of the time remaining with the same university or department. In Romania, where the educational system does not imply majors and minors, not persisting in one area of study is equivalent to dropping out, and therefore has more implications: students lose all of their credits, they lose their government-subsidized spots (if they had one); pursuing another area of study implies another entrance process/exam at another department or university, generating significant costs in terms of time and money for those students who decide to follow this route. Previous studies rarely involved 
other majors/areas of study than Engineering and while diverse ethnic samples have been studied (Hispanic, African American, and Asian American) (Flores et al., 2014; Navarro et al., 2014; Truong \& Miller, 2018), few studies were conducted outside of the US (Mujica et al., 2019). Additional studies should be conducted in other cultures and countries, and our study aims at filling this gap in research by using a Romanian sample, with conclusions that could both add validation data to the SCCT models and have practical implications for the Romanian practices in preventing university dropout.

Building on previous research that shows that the paths of the integrative model work for the prediction of persistence in other cultures and area of study, we expect that the longitudinal data collected in Romania will support the hypotheses below:

H1. Academic self-efficacy is a predictor of (and is negatively related

to) the dropout intentions, and this effect is mediated by satisfaction with the chosen area of study.

H2. Academic outcome expectations are a predictor of (and are negatively related to) the dropout intentions, and this effect is mediated by satisfaction with the chosen area of study.

\subsection{Holland's theory and vocational fit/congruence}

Holland's theory is an exponent of the larger realm of person-environment fit theories and postulates that there are 6 types of vocational interests/ personality traits that may be characteristic both for individuals and environments; these 6 form a hexagonal structure (the RIASEC hexagon): realistic $(\mathrm{R})$, investigative (I), artistic (A), social (S), enterprising (E), and conventional (C) (Holland et al., 1994). This career theory suggests that vocational congruence (fit) occurs when there is a match between one's interests and those required by different environments (e.g., work, study). When there is a match, the individual will be more satisfied and more inclined to persist in a job, educational environment, or field of study. Several types of vocational congruence indices were proposed to this effect and can be readily computed: hexagonal, Iachan, and Zener-Schnuelle (Holland et al., 1994). 
While in work environments vocational fit has been shown to be a predictor of important outcomes (Iliescu et al., 2015), the literature is split regarding the utility of vocational fit in academic contexts. Some results show that vocational congruence is associated with satisfaction and persistence in academic contexts (Nye et al., 2012; Tracey \& Robbins, 2006; Tsabari et al., 2005), while others show that it is not (Fu et al., 2019). To our knowledge, no published study investigated the utility of using SCCT and vocational congruence together. Given the split opinion about the utility of the congruence indices and the fact that the SCCT seems to explain well the persistence intention, we will investigate the following research question:

Research question: Do vocational fit indices bring an increment over social cognitive variables in explaining the intention to drop out of university?

\section{Method}

\subsection{Participants and procedure}

The sample consisted of 167 university students enlisted in a variety of programs, with ages between 17 and $32(\mathrm{M}=19.09, \mathrm{SD}=1.73)$, among them 26 males $(15.60 \%)$. The inclusion criterion was that the participants were first-year first-time university students.

The participants filled in instruments that measure self-efficacy and outcome expectations in the first weeks of enrollment in the university. Six months later, they filled out a measure of satisfaction with the chosen area of study and assessed their dropout intentions.

The instructions emphasized that the study investigated the opinion of firstyear first-time university students about university life and psychological factors in decision making and that they should answer with their own opinions at the moment of testing, in relation to the area of study they were enrolled in.

\subsection{Measures}

Academic skills self-efficacy. Self-efficacy was measured with the revised form of the Academic Behavioral Confidence (the ABC scale; Sander \& 
Sanders, 2009). In this scale, respondents assess how confident they feel about performing a series of 17 academic activities, for example: "Give a presentation to a small group of fellow students". Answers are coded on a range from 1 (not at all confident) to 5 (very confident). The Cronbach alpha coefficient for this study was .92 .

College-going outcome expectations. Outcome expectations were assessed using the Student Outcome Expectation Scale (SOES; Landry, 2003). The SOES consists of 13 items pertaining to the potential positive outcomes of attending university, with answers coded on a range from 1 (strongly disagree) to 4 (strongly agree). An example of an item is: "Getting my undergraduate degree also means I will do better with the rest of my life". The Cronbach alpha coefficient for the present study was .79.

Vocational fit (congruence). Vocational fit/congruence with the study program was measured with the 3 types of congruence indices recommended by Holland et al. (1994): Hexagonal, Iachan, and Zener-Schnuelle. The indices were computed from the participants' responses to the 66 items Activities section of the Self-Directed Search (SDS; Holland et al., 1994) and were based on two letters Holland codes. We used the official Romanian version of the SDS, with the permission of the publisher. The psychometric properties of the Romanian version of SDS are largely documented in Holland et al. (2010). The method of computation of the indices is described in detail in the technical manual for the SDS.

Satisfaction with the area of study. Satisfaction with the area of study was measured with the Academic Major Satisfaction Scale (AMSS; Nauta, 2007). This scale consists of 6 items assessing general satisfaction with the area of study on a scale ranging between 1 (strongly disagree) and 5 (strongly agree). One example of an item is "I feel good about the major I've selected". The Cronbach alpha coefficient for this study was .90. For the Romanian version, we replaced the word "major" in the items, because it does not have a correspondent in the Romanian educational system, with "profil/specializare".

Intention to drop out of the university. Dropout intentions were measured with the item "I intend to drop out this faculty", scaled between 1 (strongly disagree) and 7 (strongly agree). 
The translation and adaptation process of the ABC scale, the SOES, and the AMSS was conducted according to the guidelines for translation and adapting tests published by the International Test Commission (2017). Specifically, we employed a process of guided forward translation. Each of the authors of the present paper translated individually each item. In the process, in order to ensure the quality of the Romanian adaptation, we also used for each of the items the Item Translation and Adaptation Review Form proposed by Hambleton and Zenisky (2011). This is a 25-item checklist that assesses the translation of the items on several dimensions, such as General, Item format, Grammar and phrasing, and Culture. After the individual translation, the team reunited and analyzed the results and reached a final version of the items.

\section{Results}

Means, standard deviations, reliabilities, and correlations among variables were computed with IBM SPSS Statistics 22 (IBM Corp, 2013). The results are shown in Table no. 1. Mediation analysis was performed using both the Process macro in SPSS (Hayes, 2013) and Mplus7 (Muthén \& Muthén, 1998-2012). Full models were tested with Mplus.

Table no. 1. Means, standard deviations, reliabilities, and correlations among variables

\begin{tabular}{|c|c|c|c|c|c|c|c|c|c|c|c|}
\hline & \multirow[b]{2}{*}{ Variable } & \multirow[b]{2}{*}{$M$} & \multirow[b]{2}{*}{$S D$} & \multirow[b]{2}{*}{ Alpha } & \multicolumn{7}{|c|}{ Correlations } \\
\hline & & & & & 1 & 2 & 3 & 4 & 5 & 6 & 7 \\
\hline 1 & Self-efficacy & 92.34 & 16.50 & .92 & - & & & & & & \\
\hline 2 & Outcome expectations & 41.32 & 4.68 & .79 & $.33 * *$ & - & & & & & \\
\hline 3 & $\begin{array}{l}\text { Satisfaction with area of } \\
\text { study }\end{array}$ & 24.14 & 4.84 & .90 & $.30 * *$ & $.35 * *$ & - & & & & \\
\hline 4 & Dropout intentions & 1.49 & 1.02 & - & $-.17 *$ & $-.30 * *$ & $-.68 * *$ & - & & & \\
\hline 5 & Iachan index & 16.54 & 8.51 & - & $.16^{*}$ & .01 & $.20 *$ & $-.26 * *$ & - & & \\
\hline 6 & Hexagonal index & 3.05 & 0.90 & - & .06 & -.08 & .12 & -.13 & $.67 * *$ & - & \\
\hline 7 & Zener-Schnuelle index & 3.44 & 2.80 & - & $.17 *$ & -.01 & $.16^{*}$ & $-.20 * *$ & $.90^{* *}$ & $.54 * *$ & - \\
\hline
\end{tabular}

Note: * $p<.05, * * p<.01$

First, because the significant correlations conditions were met, we performed the mediation analyses to test $\mathrm{H} 1$ and $\mathrm{H} 2$ (Figures 1 and 2). Self-efficacy alone is related with satisfaction with area of study, $b=0.09, \mathrm{t}(165)=4.07, p<.001$. Self-efficacy alone is related with dropout intentions, $b=-0.01, \mathrm{t}(165)=-2.16$, $p<.05$. Satisfaction with area of study alone is related with dropout intentions, $b=-0.15, \mathrm{t}(165)=-11.43, p<.001$. The direct effect of self-efficacy on dropout intentions becomes statistically insignificant once we consider satisfaction with 
area of study. The Sobel test in this case supports mediation $(z=-3.82, p<$ $.001)$. For $\mathrm{H} 2$, outcome expectations alone are related with satisfaction with area of study, $b=0.36, \mathrm{t}(165)=4.81, p<001$. Outcome expectations alone are related with dropout intentions, $\mathrm{b}=-.07, \mathrm{t}(165)=-4.04, p<001$. Satisfaction with area of study alone is related with dropout intentions, $b=-.14, \mathrm{t}(165)=$ $-10.63, p<.001$. The direct effect of outcome expectations on dropout intentions becomes statistically insignificant once we consider satisfaction with area of study. The Sobel test in this case supports mediation $(z=-4.37, p<.001)$. In conclusion, the results presented above show that in both cases, satisfaction with area of study is a full mediator and $\mathrm{H} 1$ and $\mathrm{H} 2$ are supported by the data.

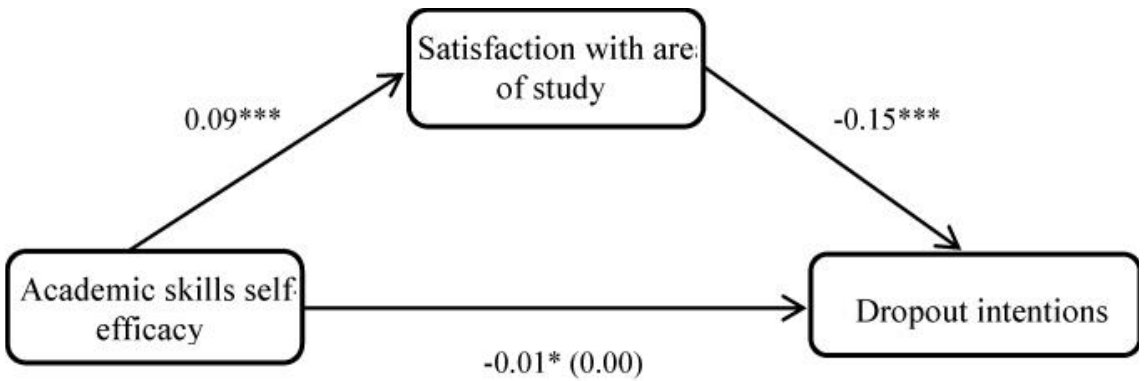

Note: * $p<.05, * * * p<.001$

Figure no. 1. Results of the mediation analysis, with satisfaction with area of study as a mediator between academic skills self-efficacy and dropout intentions

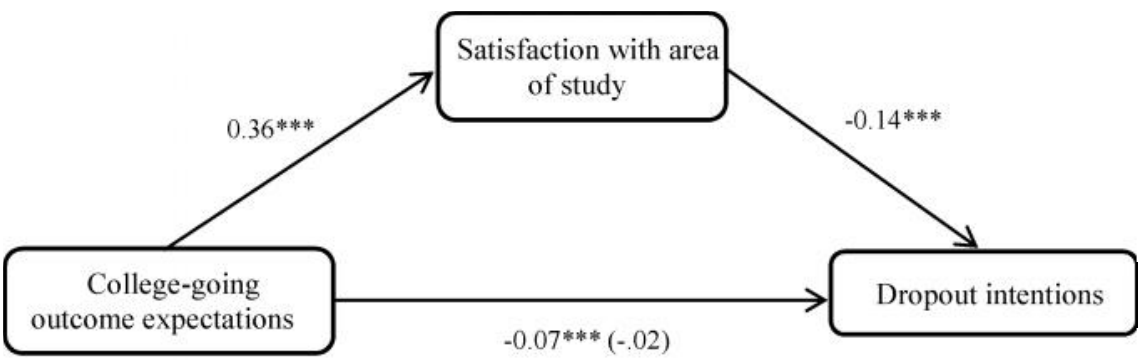

Note: $* * * p<.001$

Figure no. 2. Results of the mediation analysis, with satisfaction with area of study as a mediator between college-going outcome expectations and dropout intentions 
Furthermore, we tested different models in Mplus, in order to explore if vocational congruence has an incremental value over the social-cognitive factors in the prediction of dropout intentions. We used the Iachan and ZenerSchnuelle indices (the Hexagonal index was not used, because it was not related to the other variables).

In the first model (M1), we included the two mediations described above. Additionally, we included a path from self-efficacy to outcome expectations, which has been consistently supported in the literature (Lent \& Brown, 2019). In the second and third models (M2 and M3, respectively), in addition to $\mathrm{M} 1$, we included a path from vocational congruence (Iachan and ZenerSchnuelle, respectively) to satisfaction with area of study, because Holland's theory postulates that vocational congruence is a predictor for academic/job satisfaction. In the fourth and fifth models (M4 and M5), we also added a path from vocational congruence (Iachan and Zener-Schnuelle, respectively) to dropout intentions. For all models, we used latent variables. The fit indices for the 5 models are presented in Table no. 2. The results show that M1 has the best fit. M2 is not well fitted. In M3 and M5, although the fit indices are almost adequate, the paths from the Zener-Schnuelle congruence index are not significant. In M4, the paths from the Iachan congruence index are borderline significant $(p<.05)$. In conclusion, the best fitting model based on our data is M1, while models including congruence indices do not bring an increment in the prediction of dropout intentions. The visual representation of this model is shown in Figure no. 3.

Table no. 2. The goodness of fit statistics for the five variants of models of prediction of dropout intentions

\begin{tabular}{|c|c|c|c|c|c|c|c|}
\hline & $\chi^{2}$ & $D f$ & CFI & TLI & RMSEA & SRMR & WRMR \\
\hline M1 & $118.260^{*}$ & 6 & 0.999 & 0.998 & $0.013(0.000-0.154)$ & 0.020 & 0.319 \\
\hline M2 & $145.634^{*}$ & 9 & 0.966 & 0.925 & $0.083(0.000-0.160)$ & 0.032 & 0.500 \\
\hline M3 & $142.723^{*}$ & 9 & 0.980 & 0.955 & $0.063(0.000-0.144)$ & 0.028 & 0.477 \\
\hline M4 & $145.634^{*}$ & 9 & 0.994 & 0.983 & $0.040(0.000-0.142)$ & 0.021 & 0.345 \\
\hline M5 & $142.723^{*}$ & 9 & 0.993 & 0.979 & $0.044(0.000-0.144)$ & 0.024 & 0.400 \\
\hline
\end{tabular}

Note. $* \mathrm{p}<.0001$ 


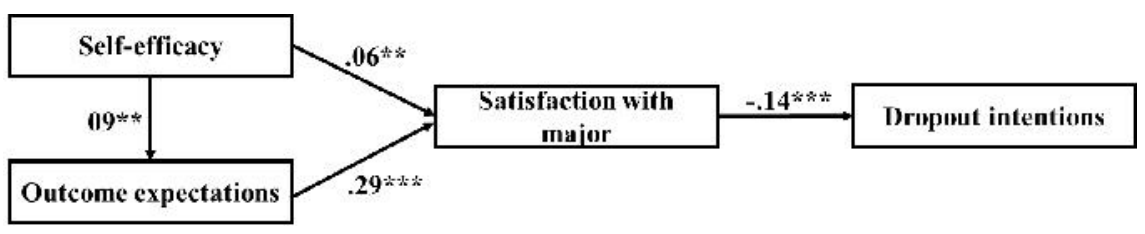

Note. $* * * \mathrm{p}<.001 ; * * \mathrm{p}<.01$

Figure no. 3. Structural path coefficients for M1

\section{Discussion}

The present study investigated the mediating effect of the satisfaction with the area of study in the relationships between self-efficacy and dropout intentions and between outcome expectations and dropout intentions; we also investigated whether Holland's congruence indices could be added to these models, for a better prediction of dropout intentions.

Both mediation hypotheses were supported by our data. This is in line with previous studies that investigated the SCCT integrative model (Lent et al., 2015; Lent et al., 2016). Those studies did not explore as outcome dropout intentions, but rather persistence intentions in the chosen area of study. Exploring dropout rather than persistence as an outcome makes more sense in Romania, because of the particularities of this context.

There are two specific features in our results that need to be discussed. In studies by Lent et al. (2013), Lent et al. (2015), and Lent et al. (2016), academic satisfaction was a partial mediator, while in our study it is a full mediator. All the effect of self-efficacy and outcome expectations is indirect, going through satisfaction with the area of study. While in previous studies self-efficacy emerged as the strongest predictor of intended persistence, for the Romanian sample, the strongest predictor is satisfaction with the area of study. This could be explained by the methodological design because self-efficacy and outcome expectations were assessed at the beginning of the freshman year, while satisfaction with the area of study and dropout intentions were assessed both at the same moment, after 6 months. 
Second, in previous studies, self-efficacy turned out to be the best predictor for academic satisfaction and persistence. In some studies, especially in longitudinal ones (Lent et al., 2016; Morris \& Lent, 2019), outcome expectations were not even a significant predictor. One interesting fact is that for our sample, outcome expectations are stronger predictors than selfefficacy for satisfaction with area of study $\left(\mathrm{r}^{2}=.12\right)$ and intention to dropout $\left(\mathrm{r}^{2}=.09\right)$. This explanatory power is even more relevant as it is obtained in a longitudinal design. This means that the satisfaction of students with their area of study comes less out of the feeling of capability, but rather out of working towards a goal (i.e., the expectation of things to happen after graduation). Future studies should investigate this characteristic in more depth. Cultural differences may play a part in this. For example, in common language in Romania, everybody asks: "what will you become after graduating from this faculty?" and not "what will you know/what will your competence be after graduating?".

The Holland congruence index is a predictor of dropout intentions in the form of Iachan and Zener-Schnuelle indices; the Hexagonal index is not a predictor of dropout intentions. The explanation could lie in the computation method for the 3 indices, with only 2 letter codes being computed for the Iachan and Zener-Schnuelle indices. Our results show that the only model in which there are significant paths from the Holland congruence indices to criteria is M5 - from the Iachan index to satisfaction with area of study and intention to drop out. However, the fit indices of the model are not better than those without the Iachan index, so our conclusion is that the congruence index does not bring an increment over social cognitive variables in explaining dropout intentions so that a model comprised only of social cognitive variables is explanatory enough.

\subsection{Theoretical and practical implications}

To our knowledge, this is the first study using the SCCT academic integrative model for the Romanian population. The study adds to the SCCT literature and validation studies by replicating the paths between the social-cognitive variables in a new culture. Also, although the model has been used in predicting persistence, this is the first longitudinal study that addresses dropout intentions. 
Recent literature recommends combining the SCCT with other theories in explaining vocational behavior (Brown \& Lent, 2019). In our study, we combined the SCCT with Holland's theory. The results show that although they are both very valid and well-studied theories in explaining human decision making, they are not useful when used together, at least for our criterion: the SCCT does a well enough job on its own in explaining dropout intentions.

The practical implications of this study are important, because of the need to devise interventions that decrease university dropout. The present investigation focused on socio-cognitive variables provides some answers in this respect. Our results show that academic self-efficacy and especially outcome expectations predict satisfaction with the area of study, which in turn predicts intentions to drop out. Consequently, the practical implication is that one way for universities to decrease students' intentions to drop out is to build their self-efficacy and outcome expectations in the first semester of the freshman year. A screening testing regarding these variables could be conducted in the first weeks at the university, as part of an "integration month" type of program. Group activities should be organized, in which students should be made systematically aware of the positive outcomes generated by graduating from university in general and from their specific area of study in particular. In these activities, academic staff should describe the opportunities awaiting after graduation, present possible jobs, organize conferences with the university alumni, etc., all with the goal of making students aware of the fact that they are in the right place that can help them to build their desired future. For those students scoring low on self-efficacy and outcome expectations, individual career counseling programs could be implemented. All these activities could be organized by the Career counseling and guidance centers available in universities.

One problem that should be addressed is the funding of these activities. The Ministerial document that governs the functioning of the career counseling and guidance centers (H.G. 650/2014) states a minimum ratio of a counselor/ psychologist per 2000 students. In practice, this number is reached by very few of the higher education career counseling centers. Another approach recommended in the literature is computing the return of investment for these activities (Johnson, 2000). They are legitimate, economically speaking, only if the amount of money lost from student dropout is higher than the 
amount spent on dropout interventions. Other sources of funding could be used for these types of activities.

\subsection{Limitations and future studies}

Several limitations should be mentioned. First, we studied intentions rather than actual drop out. There is no way of knowing how many of the participants will actually drop out. SCCT studies often mention as a limitation the fact that intention/goals are studied intensively, but few studies investigate the actual actions/implementation of career actions (Lent \& Brown, 2019). Stronger designs are also warranted, e.g. studies should investigate longitudinally one entire generation from a university area of study and explore retrospectively what combination of social-cognitive factors better predict academic dropout. However, this might prove to be challenging, because as the students become less and less involved in academic activities, they are also less prone to take part in psychological studies organized by the university. Another limitation is the small number of participants. Third, we draw attention to the sex distribution of our sample, containing many more female than male students; this may be a significant insofar as we know that there are differences between men and women with regard to types of preferred interests (Holland et al., 1994). Fourth, we used congruence indices based on two-letter Holland codes for the Iachan and Zener-Schnuelle indices, which might restrict the range of possible scores for these indices. It was not the case for the Hexagonal index, which is based only on the first letter. We did this because we compared individual codes with those of the possible qualifications offered by different areas of study, which can be very diverse with respect to secondary interest influences. More extended studies could use 3 letter indices.

The present study establishes a good replication of the most important relationships in the SCCT academic integrative model in a longitudinal design for a Romanian sample of freshmen students. It should be the base for further investigation into other variables from this model, such as environmental supports and barriers and personality traits. The results also inform future efforts by universities to build outcome expectations and selfefficacy in order to prevent dropout. 


\section{References}

- Asocia ia Na ională a Studen ilor din România. (2014). http://www.anosr.ro/ organizatiile-studentesti-ii-cer-ministrului-mihnea-costoiu-sa-isi-respectepromisiunile/

- Bean, J. P., \& Metzner, B. S. (1985). A conceptual model of nontraditional undergraduate student attrition. Review of Educational Research, 55(4), 485-540. https://doi.org/10.3102/00346543055004485

- Brown, S. D., \& Lent, R. W. (2019). Social Cognitive Career Theory at 25: progress in studying the domain satisfaction and career self-management models. Journal of Career Assessment, 27(4), 563-578.

https://doi.org/10.1177/1069072719852736

- Cabrera, A. F., Amaury, N., \& Castaneda, M. B. (1993). College persistence: structural equations modeling test of an integrated model of student retention. The Journal of Higher Education, 64(2), 123-139. https://doi.org/10.2307/2960026

- European Commission. (2010). EUROPE 2020. A strategy for smart, sustainable and inclusive growth.

https://eur-lex.europa.eu/legal-content/en/ALL/?uri=CELEX\%3A52010DC2020

- European Commission. (2019). Education and training monitor 2019. Country analysis. https://ec.europa.eu/education/sites/education/files/document-librarydocs/volume-2-2019-education-and-training-monitor-country-analysis.pdf

- Eurostat. (2020). Early leavers from education and training by sex and labour status. https://ec.europa.eu/eurostat/statistics-explainedindex.php?title=Early_ leavers_from_education_and_training

- Flores, L. Y., Navarro, R. L., Lee, H. S., Addae, D. A., Gonzalez, R., Luna, L. L., ... \& Mitchell, M. (2014). Academic satisfaction among Latino/a and White men and women engineering students. Journal of Counseling Psychology, 61(1), 81-92. https://doi.org/10.1037/a0034577

- Fu, M., Zhang, L. F., \& Li, B. (2019). Revisiting the congruence-satisfaction relationship: The role of external forces. Journal of Career Development, 46(3), 203-218. https://doi.org/10.1177/0894845317737379

- Garriott, P. O., Navarro, R. L., \& Flores, L. Y. (2017). First-generation college students' persistence intentions in engineering majors. Journal of Career Assessment, 25(1), 93-106. https://doi.org/10.1177/1069072716657533

- Gould, E. (2019). State of Working America Wages 2018. Wage Inequality Marches On—and Is Even Threatening Data Reliability. Economic Policy Institute.

- Grau-Valldosera, J., \& Minguillón, J. (2014). Rethinking dropout in online higher education: The case of the Universitat Oberta de Catalunya. International Review of Research in Open and Distributed Learning, 15(1), 290-308. https://doi.org/10.19173/irrodl.v15i1.1628 
- Hambleton, R. K., \& Zenisky, A. L. (2011). Translating and adapting tests for cross-cultural assessments. In D. Matsumoto \& F. J. van de Vijver (Eds.), Crosscultural research methods in psychology (pp. 46-70). Cambridge University Press.

- Hayes, A. F. (2013). Introduction to mediation, moderation, and conditional process analysis: a regression-based approach (1st ed.). The Guilford Press.

- Heublein, U. (2014). Student drop out from German higher education institutions. European Journal of Education, 49(4), 497-513.

https://doi.org/10.1111/ejed.12097

- Hoeschler, P., \& Backes-Gellner, U. (2017). Shooting for the stars and failing: college dropout and self-esteem (Working Paper No. 100).

http://repec.business.uzh.ch/RePEc/iso/leadinghouse/0100_lhwpaper.pdf

- Holland, J. L., Powell, A. B., \& Fritzsche, B. A. (1994). The self-directed search $(S D S)$. Psychological Assessment Resources.

- Holland, J. L., Powell, A. B., Fritzsche, B. A., Pitariu, H., Iliescu, D., \& Vercellino, D. (2010). Manual tehnic al SDS (Self-Directed Search) în România. OS România.

- IBM Corp. (2013). IBM SPSS Statistics for Windows (Version 22). IBM Corp.

- International Test Commission. (2005). International Guidelines on Test Adaptation. [www.intestcom.org].

- Iliescu, D., Ispas, D., Sulea, C., \& Ilie, A. (2015). Vocational fit and counterproductive work behaviors: A self-regulation perspective. Journal of Applied Psychology, 100(1), 21-39. https://doi.org/10.1037/a0036652

- Johnson, J. L. (2000). Learning communities and special efforts in the retention of university students: What works, what doesn't, and is the return worth the investment?. Journal of College Student Retention: research, theory \& practice, 2(3), 219-238.

https://doi.org/10.2190/V0PA-BL4B-1X2L-W5VT

- Landry, C. C. (2003). Self-efficacy, motivation, and outcome expectation correlates of college students' intention certainty (Doctoral dissertation).

http://digitalcommons.1su.edu/cgiviewcontent.cgi $?$ article=2253\&context= gradschool_dissertations

- Lee, Y., \& Choi, J. (2011). A review of online course dropout research: Implications for practice and future research. Educational Technology Research and Development, 59(5), 593-618.

- Lent, R. W., \& Brown, S. D. (2006). Integrating person and situation perspectives on work satisfaction: A social-cognitive view. Journal of Vocational Behavior, 69(2), 236-247. https://doi.org/10.1016/j.jvb.2006.02.006

- Lent, R. W., \& Brown, S. D. (2013). Social cognitive model of career selfmanagement: Toward a unifying view of adaptive career behavior across the life span. Journal of Counseling Psychology, 60(4), 557-568.

https://doi.org/10.1037/a0033446 
- Lent, R. W., \& Brown, S. D. (2019). Social cognitive career theory at 25: Empirical status of the interest, choice, and performance models. Journal of Vocational Behavior, 115, 103316. https://doi.org/10.1016/j.jvb.2019.06.004

- Lent, R. W., Brown, S. D., \& Hackett, G. (1994). Toward a unifying social cognitive theory of career and academic interest, choice, and performance. Journal of Vocational Behavior, 45(1), 79-122.

- Lent, R. W., Miller, M. J., Smith, P. E., Watford, B. A., Hui, K., \& Lim, R. H. (2015). Social cognitive model of adjustment to engineering majors: Longitudinal test across gender and race/ethnicity. Journal of Vocational Behavior, 86, 77-85. https://doi.org/10.1016/j.jvb.2014.11.004

- Lent, R. W., Miller, M. J., Smith, P. E., Watford, B. A., Lim, R. H., \& Hui, K. (2016). Social cognitive predictors of academic persistence and performance in engineering: Applicability across gender and race/ethnicity. Journal of Vocational Behavior, 94, 79-88. https://doi.org/10.1016/j.jvb.2016.02.012

- Lent, R. W., Miller, M. J., Smith, P. E., Watford, B. A., Lim, R. H., Hui, K., ... \& Williams, K. (2013). Social cognitive predictors of adjustment to engineering majors across gender and race/ethnicity. Journal of Vocational Behavior, 83(1), 22-30. https://doi.org/10.1016/j.jvb.2013.02.006

- Morris, T. R., \& Lent, R. W. (2019). Heterosexist harassment and social cognitive variables as predictors of sexual minority college students' academic satisfaction and persistence intentions. Journal of Counseling Psychology, 66(3), 308-316. https://doi.org/10.1037/cou0000341

- Mujica, A. D., Villalobos, M. V. P., Gutiérrez, A. B. B., Fernández-Castañón, A. C., \& González-Pienda, J. A. (2019). Affective and cognitive variables involved in structural prediction of university dropout. Psicothema, 31(4), 429-436. https://doi.org/10.7334/psicothema2019.124

- Muthén, L. K., \& Muthén, B. O. (1998-2012). Mplus User's Guide. Seventh Edition. Muthén \& Muthén.

- Nauta, M. M. (2007). Assessing college students' satisfaction with their academic majors. Journal of Career Assessment, 15(4), 446-462. https://doi.org/10.1177/1069072707305762

- Navarro, R. L., Flores, L. Y., Lee, H. S., \& Gonzalez, R. (2014). Testing a longitudinal social cognitive model of intended persistence with engineering students across gender and race/ethnicity. Journal of Vocational Behavior, 85(1), 146-155. https://doi.org/10.1016/j.jvb.2014.05.007

- Nye, C. D., Su, R., Rounds, J., \& Drasgow, F. (2012). Vocational interests and performance: A quantitative summary of over 60 years of research. Perspectives on Psychological Science, 7(4), 384-403. https://doi.org/10.1177/1745691612449021

- Robbins, S. B., Lauver, K., Le, H., Davis, D., Langley, R., \& Carlstrom, A. (2004). Do psychosocial and study skill factors predict college outcomes? A meta- 
analysis. Psychological Bulletin, 130(2), 261-288.

https://doi.org/10.1037/0033-2909.130.2.261

- Rodríguez-Gómez, D., Feixas, M., Gairín, J., \& Muñoz, J. L. (2015). Understanding Catalan university dropout from a cross-national approach. Studies in Higher Education, 40(4), 690-703. https://doi.org/10.1080/03075079.2013.842966

- Sander, P., \& Sanders, L. (2009). Measuring academic behavioural confidence: the ABC scale revisited. Studies in Higher Education, 34(1), 19-35. https://doi.org/10.1080/03075070802457058

- Stăiculescu, C., \& Richi eanu-Năstase, E. R. (2018). University dropout. Causes and solution. Mental Health: Global Challenges Journal, 1(1), 71-75.

- Tinto, V. (1975). Dropout from higher education: A theoretical synthesis of recent research. Review of Educational Research, 45(1), 89-125. https://doi.org/10.3102/00346543045001089

- Tracey, T. J., \& Robbins, S. B. (2006). The interest-major congruence and college success relation: A longitudinal study. Journal of Vocational Behavior, 69(1), 64-89. https://doi.org/10.1016/j.jvb.2005.11.003

- Truong, N. N., \& Miller, M. J. (2018). Family and social cognitive predictors of southeast Asian American college students' academic satisfaction. Journal of Career Assessment, 26(3), 488-502. https://doi.org/10.1177/1069072717714543

- Tsabari, O., Tziner, A., \& Meir, E. I. (2005). Updated meta-analysis on the relationship between congruence and satisfaction. Journal of Career Assessment, 13(2), 216-232. https://doi.org/10.1177/1069072704273165

- Varly, P., Iosifescu, C. Ş., Fartuşnic, C., Andrei, T., \& Her eliu, C. (2015). Costul investi iei insuficiente în educa ie în România: raport final pentru UNICEF. Alpha MDN.

The online version of this article can be found at: http://revped.ise.ro/category/2020-en/

\section{(c) EY-NG-sA}

This work is licensed under the Creative Commons Attribution-NonCommercial-ShareAlike 4.0 International License.

To view a copy of this license, visit http://creativecommons.org/licenses/by-nc-sa/4.0/ or send a letter to Creative Commons, PO Box 1866, Mountain View, CA 94042, USA.
Versiunea online a acestui articol poate fi găsită la: http://revped.ise.ro/category/2020-ro/

\section{$( c c ) \longdiv { B R - N C - s h }$}

Această lucrare este licen iată sub Creative Commons Attribution-NonCommercial-ShareAlike 4.0 International License.

Pentru a vedea o copie a acestei licen e, vizita $i$ http://creativecommons.org/licenses/by-nc-sa/4.0/ sau trimite i o scrisoare către Creative Commons, PO Box 1866, Mountain View, CA 94042, SUA. 